\title{
Determinants of Credit Risk in the Banking Sector of Ghana: A Panel Co-integration Approach
}

\author{
T. Appiah, and F. Bisiw
}

\begin{abstract}
The economic development of any nation hinges on the health of its financial system. In recent years, the health of the Ghanaian Banking sector has been affected severely as a result of high levels of non-performing loans (NPLs), which has been identified as a major threat to the overall profitability and survival of banks. To minimize the impact of NPLs on the financial sector, key stakeholders such as the government, bank officials and regulators are working hard in that regard. However, any policy response aimed at dealing with the high rate of non-performing loans first requires the understanding of the underlying determinants of NPLs. Against this backdrop, this paper apply panel co-integration techniques to investigate the determinants of credit risk (NPLs) in the banking sector of Ghana. We use NPL as a proxy to measure credit risk and assess how it is influenced by macroeconomic and bank-specific factors. A balanced panel data of $\mathbf{1 6}$ universal banks in Ghana from 2010 to 2016 has been analyzed using Panel co-integration techniques such as Fully Modified Ordinary Least Squares (FMOLS) and Dynamic Ordinary Least Squares (DOLS). Our result shows that growth in the economy, measured by Gross Domestic Product (GDP) has significant influence on the NPLs of banks in the long-run. The results further revealed that capital adequacy, profitability and liquidity of banks are significant predictors of NPLs. However, our results suggest that bank size, inflation and interest rate have statistically insignificant influence on the NPLs of Ghanaian banks. The study recommend, among others, that whereas it is important for government and policymakers to work to improve macroeconomic outcomes, banks should also improve their capital adequacy, profitability, and efficiency position as these bank-specific interventions could significantly improve credit quality and minimize NPLs.
\end{abstract}

Index Terms - Banking Sector, Credit risk; Ghana, Panel Cointegration.

\section{INTRODUCTION}

Financial institutions, especially banks, are critical to the growth and development of every economy. In developing countries, where the financial system is still developing, banks are crucial in ensuring that the financial system remains robust to support the economy. According to [1], the full economic potential of a nation is realized when it has a healthy financial system. The author further argues that for developing countries to improve the living standards of their people, a well-functioning financial system, of which banks are a critical part, must be established. In developing countries, banks are the mainstay of the financial system and therefore their growth and survival are of significant importance for the survival of the financial system as a whole.
To remain profitable and survive, these banks must earn revenue through their operations. A significant part of the banking sector's revenue in developing countries like Ghana is obtained from interest income. Banking institutions, as part of their financial intermediation role, advance loans to businesses and individuals and receive interest income as part of the transaction. This business model is accompanied by default risk (credit risk), which is the possibility that borrowers will fail to repay loans advanced to them by financial institutions [2]. Default (credit) risk, which is often represented by Non-Performing Loans (NPLs), has been identified as one of the biggest challenges facing financial institutions in their day to day operations. For instance, [3] has acknowledged credit risk as the most prevailing risk confronting the banking sector. This view is shared by [4] who describe credit risk as a major cause of bank failure. Bernanke [1] has also opined that high levels of NPLs have the potential to undermine the banking system and the financial system in general. It is therefore important that policies and programs are instituted to avert or minimize the possible negative consequences of credit risk on the banking sector. It must, however, be noted that any policy response aimed at dealing with credit risk will first require an understanding of the underlining determinants of NPLs.

In Ghana, the banking sector has been grappling with high NPLs over the past two decades. This has compelled many banks and loan granting institutions to develop strategies to deal with the problem. As part of their strategies, banks cleaned their books and introduced robust credit granting and monitoring policies to minimize loan impairment. To minimize the high credit risk and its impact on the economy, the Bank of Ghana (BOG) introduced legislation which saw the establishment of three credit bureau institutions for effective credit administration within the banking industry [5]. Although these changes by financial institutions and the central government yielded some significant results, the banking industry of Ghana continues to record high levels of non-performing. Although a cursory look at the nonperforming loans to total assets ratio (NPL/TA) of Ghanaian banks from 2011 to 2015 indicates a downward trend, the ratio is still very high compared to other developed and other African countries. For instance in Figure 1, it is observed that even though the level of NPLs is witnessing downward trend, it is still high when compared with other developed and African countries. Also, the rate of NPLs within the banking sector of Ghana way above the five percent benchmark 
recommended by the Basel II. The high levels of NPLs in Ghana, if left unchecked, may not only threaten the survival of these banks but could also negatively affect the financial system and the economy as a whole [6]. The focus of this study is to investigate both banks-specific and macroeconomic determinants of NPLs in Ghana. Given the fact that the financial sector is a cornerstone for the overall economic development of a country, understanding the factors affecting credit risk in the banking industry will help banks and the regulator (Bank of Ghana) to develop policies that will lead to the effective and efficient management of credit risk. Furthermore, the findings of the study will help the government to improve the macro-economic environment to minimize credit risk associated with banking.

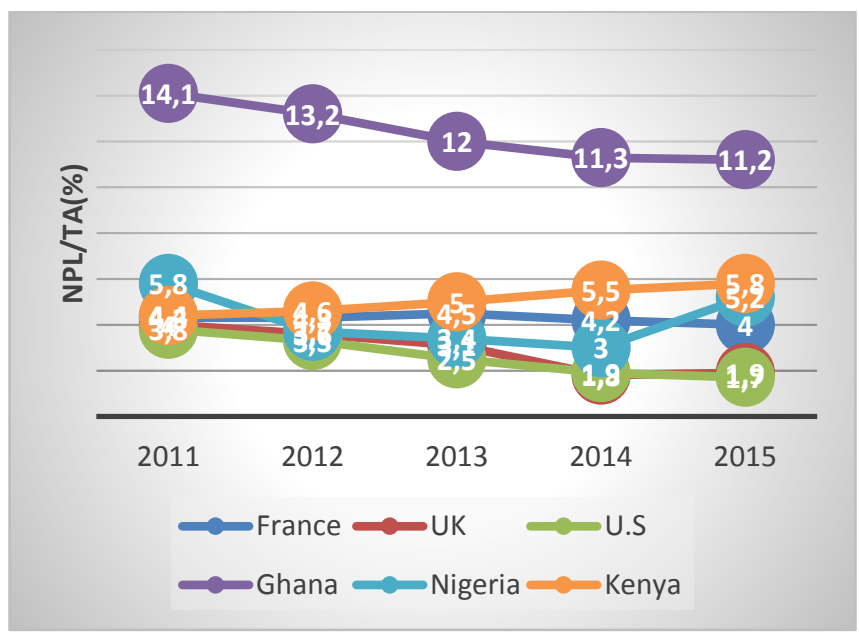

Fig. 1. Comparison of NPLs Ratios of Selected Countries

This paper is different from other papers in the following respect: First, whereas some studies have investigated the determinants of credit risk in Ghana and elsewhere [7], these studies have mainly been conducted using pooled ordinary least square (OLS) regression techniques, which fails to eliminate sample bias and serial correlation effects [8]. This paper adopts a more robust analysis of the data using panel cointegration estimation techniques such as FMOLS and DOLS. These techniques do not only correct endogeneity and serial correlation effects in the data but they also eliminate sample bias asymptotically [9]. Also, whereas many empirical studies have focused on the determinants of credit risk by focusing on cross-country analysis, this paper focuses on single-country case analysis of the determinants of credit risk, which is important in ascertaining the countryspecific determinants of NPLs.

The rest of the paper is structured as follows: Section two provides a review of the literature on credit risk and its determinants. Section three describes the dataset and the econometric techniques applied to estimate the data. Section four presents the results of the data and its interpretation. Finally, section five concludes the paper and outlines policy and managerial implications.

\section{LITERATURE REVIEW}

\section{A. Overview of Credit Risk and its Determinants}

Various empirical studies are available to explain the macro-economic and bank-specific factors that affect NPLs within the financial sector. These empirical studies have been conducted within different theoretical frameworks. For instance, empirical studies examining the macro-economic factors affecting credit risk have been conducted using the financial accelerator theory, which seeks to link the economy to the financial sector and its performance [10], [11]. Aside macroeconomic factors, internal operations of banks and some operational decisions, often referred to as bank-specific factors, may also influence NPLs. Whereas the macroeconomic factors consider economic variables such as gross domestic product (GDP), inflation, interest rate, exchange rate and financial crises and instability [12], bankspecific factors are concerned about management and internal decisions that could influence non-performing loans [13], [14].

Over the years, empirical studies have been carried out to investigate the determinants of credit risk. These studies have been undertaken in both developed and developing economies. A cursory examination of these studies reveals that the reasons for NPLs are diverse and multi-dimensional. Generally, empirical studies examining the determinants of credit risk has been done based on macro-economic and banks specific drivers. For instance, Ali and Daly [15] examined the macroeconomic factors affecting credit risk in the financial industry. The study was conducted among universal banks in the United States of America (USA) and Australia. A logit model was employed on data from the period 1995-2009. The findings of the study revealed that Gross Domestic Product (GDP), interest rates and total debts significantly affect credit risk. Their study further found that the USA economy is weak to macroeconomic shocks than its Australia counterpart.

In Sub-Saharan Africa, [16] examined the macroeconomic factors that influence credit risk using 22 countries within SSA. The study employed panel data techniques to examine the influence of macro-economic factors on the nonperforming loan ratios (NPLs) of the selected countries. Data for the study was collected from the period spanning from the year 2000 to 2016. The result of the study revealed that economic growth, measured by gross domestic product (GDP) has a significant negative effect on credit risk. The result further revealed that the global financial crises of 2005 and inflation rate had a significant positive effect on nonperforming loans on financial institutions. Also [13] determined the macro-economic determinants of credit risk using time series data from South Africa, Kenya, Namibia, Uganda, and Zambia. Furthermore, [17] and [18] have also applied ordinary least squares (OLS) techniques to examine credit risk determinants in Nigeria and Uganda respectively. In developed and developing countries, some empirical studies have also been conducted on credit risk determinants. For instance, [19] after conducting a cross-country analysis of the determinants of credit risk within the banking, sector found that GDP growth reduces NPLs within the banking sector. Similarly, [20] also observed that exchange rate 
depreciation and unemployment are associated positively with NPLs, implying that an increase in these factors leads to increases in credit risk.

A careful analysis and evaluation of the existing literature on the determinants of NPLs reveals that the majority of the studies have focused mainly on the macroeconomic determinants of credit risk. This paper makes a significant contribution to the existing literature by investigating both the macroeconomic and bank-specific determinants of NPLs. Also, significant number of studies carried out so far have focused on cross-country analysis of credit risk, with little consideration for country-specific determinants. This research, thus provides additional understanding of the determinants of credit risk in Ghana by focusing of macroeconomic and bank-specific factors.

\section{B. Brief Overview of the Ghanaian Banking industry}

Before the colonial era, there were no formal financial/banking institutions in Ghana, although some form of arrangement was made to ensure that funds are transferred from individuals with surplus funds to deficit units. The beginning of colonial rule in Ghana witnessed the setting up of banking institutions. The successful establishment of the British Bank of West Africa (BBWA) spurred the introduction of more banking institutions in Africa. Barclays Bank and Standard Chartered Bank were the only two banks which operated between 1920 and 1950 in the then Gold Coast. These banks were set up to support the trading activities of the colonial government and to offer some form of financial services to the people of the Gold Coast (now Ghana). New branches of the two banks were opened in other colonies such as the Ashanti and Northern areas to facilitate the trading activities of the British. In 1953, the British established the bank of Gold Coast, which was later separated into the bank of Ghana (BOG) and Ghana Commercial Bank.

After gaining independence from the British in 1957, massive investment was made in the banking sector to support the new government's agenda of industrialization. Additional banks which were established between 1957 and 1965 includes the Agricultural Development Bank (ADB), Merchant Bank, and the Social Security Bank. These banks were set up by the government to support agriculture and trade, and to encourage savings among the general population. From 1957 to 1989 , the Ghanaian banking sector was dominated by state owned banks. However, in 1989 the banking sector was given an additional boost through the enactment of the banking law, which paved the way for private sector participation in the banking sector. As of 2014, a total of 29 commercial banks have been established to support the banking needs of Ghanaians [21].

The Ghanaian banking crisis in 2017, however, led to the collapse of some banks. The failure of these banks was attributed to the high levels of NPLs, low capital adequacy, and poor corporate governance practices [22]. Even though steps have been taken by the BOG to clean the banking sector and make it more robust, there are still macro-economic and bank-specific factors that could militate against the banking sector and the financial system in general. It is therefore crucial that research is conducted into the main macroeconomic and bank-specific factors that could affect NPLs in the country.

\section{Methodology}

\section{A. Data Source}

Data for the study was obtained from two main sources, audited financial statements from selected universal banks in Ghana and macroeconomic data from the Bank of Ghana and the Ghana Statistical Service (GSS). In addition to these sources, other information was obtained from the World Bank Development Indicators which is published on annual basis The data was collected from the period 2010 to 2016 . The bank-specific variables considered in this research include non-performing loan ratio, which was used as a proxy to measure credit risk, the cost to income ratio, liquidity, profitability, capital adequacy ratio, and bank size. The dependent variable and independent variables, together with their measurement are presented in Table 1.

TABLE 1: VARIABLES AND THEIR MEASUREMENT

\begin{tabular}{|c|c|}
\hline Variable & Measurement \\
\hline $\begin{array}{l}\text { Nonperforming } \\
\text { loan ratio } \\
\text { (NPLs)/CR }\end{array}$ & $\begin{array}{c}\text { Calculated as nonperforming loans to the gross } \\
\text { loan (Used as a proxy for credit risk) }\end{array}$ \\
\hline $\begin{array}{l}\text { Cost-Income Ratio } \\
\text { (CIR) }\end{array}$ & Calculated as total cost divided by total income \\
\hline $\begin{array}{l}\text { Capital Adequacy } \\
\text { (CAR) }\end{array}$ & $\begin{array}{c}\text { (Tier } 1 \text { capital +Tier } 2 \text { capital)/Risk weighted } \\
\text { assets } \\
\end{array}$ \\
\hline Liquidity (LIQ) & Calculated as: Total Loans/Total deposit \\
\hline $\begin{array}{l}\text { Profitability } \\
\text { (PROF) }\end{array}$ & Calculated as net profit to total assets \\
\hline $\begin{array}{l}\text { Size of the Bank } \\
\text { (SIZE) }\end{array}$ & Measured as the logarithm of total assets \\
\hline Inflation (INF) & Proxy for consumer price index \\
\hline GDPG & Calculated as the growth in GDP \\
\hline Interest rate (ITR) & Proxy for policy rate of the Bank of Ghana \\
\hline
\end{tabular}

Source: Author's Computation Using Eviews

\section{B. Panel unit root Test}

Determining the order of integration of the variables is important as the variables must be integrated at order I (1) in order to apply panel cointegration techniques such as FMOLS and DOLS. To confirm the I(1) properties of the variables, all variables are tested for unit roots using tests by Levin, Lin and Chu (LLC), Breitung, and Im, Pesaran and Shin. The general model specifying the Levin, Lin and Chu (LLC) unit root test is given as:

$$
\Delta Y_{i, t}=\alpha_{i}+\rho Y_{i, t}+\sum_{k=1}^{n} \theta_{k} \Delta Y_{i, t-k}+\sigma_{i} t+\varphi_{t}+\mu_{i t},(1)
$$

From (1), the deterministic component is given by $\sigma_{i} t+\varphi$, $Y_{i, t}$ is the variable being tested for unit root, $\alpha$ is the constant, $t$ represent the time trend variable, and $n$ is the number of lags. The above specification allows for two-way fixed effects. According to [23], the LLC test take in accounts both time-specific effect and unit-specific effect. Again, the test controls for heterogeneity originating from the individual units captured in the model. The null hypothesis of the existence of stationarity is in all the variables, $H_{0}: \rho=0$ ) is compared with the alternative hypothesis of; $H_{1}: \rho<0$ in all the variables. 


\section{Model specification}

The general model for estimating the relationship between the dependent and independent variables is given by:

$$
N P L_{i t}=\alpha_{i}+\delta_{i} t+\beta_{M E F} X_{i t}^{M E F}+\beta_{B S F} X_{i t}^{B S F}+\varepsilon_{i, t}
$$

where: $i$ and $t$ represents the cross-sectional elements (bank) and time period, respectively;

$N P L_{i t}$ is the dependent variable;

$\varepsilon_{i t}$ represents the error term;

$\delta_{i} t$ Unobserved individual effects;

$\alpha_{i}$ represents the intercept;

$\beta_{M E F}$ and $\beta_{B S F}$ are the coefficients (vector) to be estimated; $X_{i t}^{M E F}$ and $X_{i t}^{B S F}$ are the macroeconomic variables and bankspecific variables to be estimated, respectively.

This general model is transformed into FMOLS and DOLS modelS as follows:

Given the cointegrating equation

$$
y_{t}=X^{\prime} \beta+D_{1 t}{ }^{\prime} \gamma_{1}+\varepsilon_{i t}
$$

where: $D_{t}=\left(D_{1 t}{ }^{\prime}, D_{1 t}\right)^{\prime}$ is represented by the deterministic trend repressors, $X^{\prime}$ as transformed independent variables; $y_{t}$ as the dependent variable;

If $\varepsilon_{1 t}$ are the residuals obtained from (3), then $\varepsilon_{2 t}$ can be obtained indirectly as $\varepsilon_{2 t}=\Delta \widehat{\epsilon}_{2 t}$ from the levels regressions,

$$
X_{t}=\widehat{\Gamma}_{21}{ }^{\prime} D_{1 t}+\widehat{\Gamma}_{22}{ }^{\prime} D_{1 t} D_{2 t}+\widehat{\epsilon}_{2 t}
$$

Or directly firm the differenced regressions

$$
\Delta X_{t}=\widehat{\Gamma}_{21}{ }^{\prime} D_{1 t}+\widehat{\Gamma}_{22}{ }^{\prime} D_{1 t} D_{2 t}+\varepsilon_{2 t}
$$

If $\hat{\Omega}$ and $\hat{\Lambda}$ are used to represent the long-run covariance matrices computed through the use of the residual

$$
\varepsilon_{t}=\left(\varepsilon_{1 t}, \varepsilon_{2 t}^{\prime}\right)^{\prime}
$$

then the modified data can be defined by

$y_{t}^{+}=y_{t}-\widehat{\omega}_{12} \Omega_{22}^{-1}+\varepsilon_{2}$

With an estimated bias correction term given as

$$
y_{12}{ }^{+}=\hat{\lambda}_{12}-\widehat{\omega}_{12} \Omega_{22}^{-1}+\hat{\Lambda}_{22}
$$

FMOLS estimation constructs the covariance matrix represented by $\hat{\Omega}$ and $\hat{\Lambda}$.

The FMOL estimator is therefore given by

$$
\hat{\theta}=\left[\begin{array}{c}
\beta \\
\hat{\gamma}_{1}
\end{array}\right]=\left(\sum_{t-2}^{T} Z_{t} Z_{t}^{\prime}\right)^{-1}\left(\sum_{t-2}^{T} Z_{t} y_{t}{ }^{+}-T\left[\begin{array}{c}
\lambda^{+}{ }_{12}{ }^{\prime} \\
0
\end{array}\right]\right)
$$

where

$$
Z_{t}=\left(X_{t}^{\prime}, D_{t}^{\prime}\right)^{\prime}
$$

The estimator in equation (8) can be written in a simple form as:

$$
\boldsymbol{\beta}_{i}^{*}=\left(\boldsymbol{X}_{\boldsymbol{i}}^{\prime} \boldsymbol{X}\right)^{-1}\left(\boldsymbol{X}^{\prime}, \boldsymbol{y}^{*}{ }_{i}-\boldsymbol{T} \boldsymbol{\delta}\right)
$$

where $y^{*}$ is the transformed endogenous variable, $\delta$ is the parameter that adjust for autocorrelation in the model, and $T$ is the number of time periods.

The DOLS augments the cointegrating regression with lags and lead of $\Delta X_{t}$, in the equation so that the cointegration equation becomes;

$$
y_{t}=X_{t}^{\prime} \beta+D_{1 t}^{\prime} \gamma_{1}+\sum_{j=-q}^{r} \Delta X_{t+j}^{\prime} \delta+v_{1 t}
$$

where $q$ and $r$ are the lags and leads of the equation, respectively.

The least-squares estimate of $\theta=\left(\beta, \gamma^{\prime}\right)^{\prime}$ using the equation (5) has similar asymptotic distribution as the one obtained from the FMOLS estimations.

\section{PRESENTATION AND DISCUSSION OF RESULTS}

\section{A. Descriptive Statistics and Correlation Analysis}

The main features of the data were examined using descriptive measures such as the mean, minimum and maximum values, as well as the standard deviation. This result is captured in Table 2 . The average capital adequacy ratio (CAR) for the selected banks is 0.132 or $13.2 \%$, with minimum and maximum values of 0.359 and 0.009 respectively. The result also shows that the average efficiency (measured by cost to income ratio) of the selected banks within the study period was 0.608 or $60.8 \%$ with a standard deviation of $19.2 \%$. This result indicates that banks on average spent over 60 pesewas for every 1 cedi of income generated. The average credit risk, measured by loan loss provision to gross loan advances for the period is 0.1295 or $12.95 \%$. This result means that almost $13 \%$ of the total loans advanced by the selected banks within the study period were considered as non-performing. As far as liquidity (LIQ) of the selected banks is concerned, it can be observed that the average for the period is $45.2 \%$. This implies that over $45 \%$ of the assets of the selected companies are tied up in loans. The PROF (return on assets), which is being used as a measure of profitability in this study has an average value of 0.027 or $2.7 \%$. This result indicates that the selected banks were on average able to generate $2.7 \%$ return on their total assets. Concerning the macroeconomic variables, it can be observed that the average growth in GDP over the period (from 2010 to 2017) was 6.97\%. The average inflation figure for the period was $13.9 \%$ which means that on average, prices of goods and services within the period rose by $13.9 \%$. This result indicates that over the period, inflation was substantially high and could affect the non-performing loans of the banks if not anticipated. The result also shows that the average interest rate for the period is $15.8 \%$ which is substantially high for borrowers.

The correlation results, as shown in Table 3 presents the relationship between the study variables. It provides evidence to understand the association (both direction and magnitude) among the study variables. It also helps to examine whether multicollinearity exists among the independent variables. Mela \& Kopalle [24] argue that the existence multicollinearity among independent variables affects the value of the coefficient estimates and also overestimate the 
R-square of the regression model. Green et al. [25] and [26] have suggested thresholds for determining the existence of multicollinearity among independent variables. For instance, [25] suggest that a coefficient of 0.9 or more suggest that there is a problem of multicollinearity, whereas [26] set the threshold to 0.7 or more. From the result in Table 3, it can be observed that none of the correlation coefficients among the independent variables exceeds the threshold of 0.7 . Thus, it can be concluded that there is no problem of multicollinearity among the variables.

TABLE 2: DESCRIPTIVE STATISTICS OF STUDY VARIABLES

\begin{tabular}{|c|c|c|c|c|c|}
\hline Variable & Mean & Max & Min & S.D & Observations \\
\hline CAR & 0.1322 & 0.359 & 0.090 & 0.055 & 112 \\
\hline CIR & 0.6084 & 0.695 & 0.001 & 0.192 & 112 \\
\hline NPL(CR) & 0.1295 & 0.550 & 0.008 & 0.096 & 112 \\
\hline GDPG & 6.9724 & 14.046 & 3.985 & 2.675 & 112 \\
\hline INF & 13.931 & 26.674 & 8.726 & 4.907 & 112 \\
\hline ITR & 15.797 & 21.500 & 12.500 & 2.573 & 112 \\
\hline LIQ & 0.452 & 0.714 & 0.147 & 0.122 & 112 \\
\hline PROF & 0.027 & 0.147 & -0.075 & 0.027 & 112 \\
\hline SIZE & 19.810 & 20.414 & 16.251 & 3.154 & 112 \\
\hline
\end{tabular}

KEY: CAR (Capital adequacy ratio); CIR (Cost to income ratio) CR (Credit risk); GDPG (growth in gross domestic product); INF (inflation rate), INT (interest rate), LIQ (liquidity), PROF (Profitability) Size (Log of total assets).

Source: Author's Computation Using Eviews.

TABLE 3: CORRELATION BETWEEN STUDY VARIABLES

\begin{tabular}{|c|c|c|c|c|c|c|c|c|c|}
\hline & CAR & CIR & GDPG & $\mathrm{CR}$ & INF & ITR & LIQ & PROF & SIZE \\
\hline CAR & 1.000 & & & & & & & & \\
\hline CIR & -0.104 & 1.000 & & & & & & & \\
\hline GDPG & 0.065 & 0.123 & 1.000 & & & & & & \\
\hline $\mathrm{CR}$ & 0.153 & -0.137 & 0.111 & 1.000 & & & & & \\
\hline INF & -0.039 & -0.086 & -0.457 & 0.008 & 1.000 & & & & \\
\hline ITR & -0.039 & -0.152 & -0.414 & 0.050 & 0.653 & 1.000 & & & \\
\hline LIQ & -0.079 & 0.025 & 0.070 & 0.027 & -0.059 & -0.143 & 1.000 & & \\
\hline PROF & 0.200 & -0.511 & -0.114 & -0.085 & -0.048 & -0.023 & -0.018 & 1.000 & \\
\hline SIZE & 0.019 & -0.152 & -0.202 & 0.136 & -0.127 & -0.124 & 0.329 & 0.189 & 1.000 \\
\hline
\end{tabular}

Source: Author's Computation Using Eviews.

\section{B. Results of Panel Unit Root Test}

An important requirement for the use of P-FMOLS and PDOLS is that the variables must be I (1). To examine the stationarity of the variables, three main models were used. These are Levin, Lin and Chu [27] Breitung [28] and Im, Pesaran and Shin [29]. Whereas the first two tests assume a common unit root process, the last test assumes an individual unit root process. In this test, the null hypothesis of unit root (non-stationarity) is tested against the alternative hypothesis of no unit root. Table 4 depicts the results of the panel unit root tests. The result of the various tests shows that the variables are non-stationary at their level forms but become stationary when they are first differenced. This means that all the variables are integrated in order one (ie I(1)). This result indicates that the data is suitable for panel cointegration test as proposed by [30].
TABLE 4: RESULTS OF PANEL UNIT ROOT TEST AT FIRST DIFFERENCED

\begin{tabular}{ccccc}
\hline Variable & LLC & Breitung & IPS & $\begin{array}{c}\text { Level of } \\
\text { integration }\end{array}$ \\
\hline CAR & $-6.67 * *$ & 0.22 & $-3.35 * *$ & $\mathrm{I}(1)$ \\
CIR & $-4.77 * *$ & $-2.31 *$ & $-3.57 * *$ & $\mathrm{I}(1)$ \\
CR & $-11.21 * *$ & -0.01 & $-3.96 * *$ & $\mathrm{I}(1)$ \\
PROF & $-3.76 * *$ & 0.56 & $-2.55 * *$ & $\mathrm{I}(1)$ \\
SIZE & $-1.29 *$ & 0.64 & $-1.28 *$ & $\mathrm{I}(1)$ \\
GDPG & $-5.312 * *$ & $-10.60 * *$ & $-3.29 * *$ & $\mathrm{I}(1)$ \\
INF & $-13.32 * *$ & 0.36 & $-11.49 * *$ & $\mathrm{I}(1)$ \\
ITR & $-17.17 * *$ & $-3.59 * *$ & $-11.56 * *$ & $\mathrm{I}(1)$ \\
LIQ & $-4.76 * *$ & $-2.21 *$ & $-3.56 * *$ & $\mathrm{I}(1)$ \\
\hline and $* *$ represents the rejection of the null hypothesis at $5 \%$ and $1 \%$
\end{tabular}

$*$ and $* *$ represents the rejection of the null hypothesis at $5 \%$ and $1 \%$ significance levels, respectively.

\section{Results of Panel Cointegration Tests}

Two main tests were conducted to determine the cointegration relationship between the variables. These are 
the Pedroni's [30] panel cointegration test and Kao's [31] panel cointegration test. The Pedroni's cointegration test utilizes seven main statistics, comprising of four panel statistics and three group statistics. The null hypothesis of no cointegration is tested against the alternative hypothesis of at least one cointegration equation. The seven statistics are panel v-statistics, panel rho-statistics, panel PP-statistic, panel ADF-statistic, group rho-statistic, group PP-statistic, and group ADF statistics. From the results presented in Table 5 , out of the seven statistics reject the null hypothesis of no cointegration. Three of the tests fail to reject the null hypothesis of no cointegration among the variables. The null hypothesis of no cointegration is rejected when these statistics have large negative values and significant at 5 or 1 per cent level. However, the overall implication is that we fail to reject the null hypothesis of no cointegration. This is because four out of the seven statistics reject the null hypothesis at a $1 \%$ level of significance [30]. According to [30], PP test and p-stats normally reject the null hypothesis when the sample size is small. Thus, it can be concluded that concerning the Pedroni's residual cointegration test, the null hypothesis of no cointegration is rejected, meaning that there is cointegration among the variables. Also, the Kao ADF test has a statistic of -6.99 and a p-value which is less than 0.05 . This indicates that the null hypothesis of no cointegration is rejected in favour of the alternative hypothesis. Thus, it can be concluded that both Pedroni's test and Kao's test provides evidence to prove that there is cointegration among the variable.

\begin{tabular}{lcc}
\multicolumn{3}{c}{ TABLE 5: PANEL COINTEGRATION TEST } \\
\hline \multicolumn{1}{c}{ Test Name } & Test Statistic & P-Value \\
\hline Pedroni 's Residual cointegration test & & \\
Panel v-Statistic & -0.587320 & 0.7215 \\
Panel rho-Statistic & 2.414901 & 0.9921 \\
Panel PP-Statistic & $-12.71339^{* *}$ & 0.0000 \\
Panel ADF-Statistic & $-9.576426^{* *}$ & 0.0000 \\
Group rho-Statistic & 5.048300 & 0.9900 \\
Group PP-Statistic & $-16.84818^{* *}$ & 0.0000 \\
Group ADF-Statistic & $-7.034849^{* *}$ & 0.0000 \\
Koa Residual Cointegration test & & \\
ADF Statistic & $-6.997278^{* * *}$ & 0.0000 \\
\hline
\end{tabular}

ifnificant at $1 \%$ level.

Source: Author's Computation Using Eviews.

\section{FMOLS and DOLS Results}

Since previous sections have examined the unit root and cointegration properties of the study variables, this section examines the influence of the independent variables (explanatory variables) on NPLs. The estimate of the relationship between the dependent variable (NPL) and the independent variables is presented in Table 6 . The first, second and third columns present the OLS, FMOLS and PDOLS estimate respectively.

The result shows that both macro-economic factors and bank-specific factors influence NPLs (credit risk). For instance, among the three macroeconomic variables, growth in GDP is found to have a significant negative relationship with NPLs in the long run as shown in both models 2 and 3. This result suggests that strong economic performance, supported by increasing GDP, leads to lower NPLs within the banking sector. Put differently, economic growth has the likelihood to minimize the rate of loan default.

One possible reason for this outcome is that growth in the economy usually translate into high incomes for households and businesses and hence improvement in their debt servicing capabilities. Banks are also able make more profit in periods of economic growth and therefore may not be too desperate to engage in risky lending activities that may affect their credit quality. This result is consistent with the findings of the studies carried out by [15], [16], and [19], which found significant negative relationship between NPLs and GDP growth.

TABLE 6: REGRESSION RESULTS

\begin{tabular}{|c|c|c|c|}
\hline Variables & $\begin{array}{l}\text { Model } 1 \\
\text { (OLS) }\end{array}$ & $\begin{array}{c}\text { Model } 2 \\
(\mathrm{P}-\mathrm{FMOLS})\end{array}$ & $\begin{array}{c}\text { Model } 3 \\
\text { (P-DOLS) }\end{array}$ \\
\hline \multirow{2}{*}{ Inflation } & -0.8944 & 0.4222 & -0.0025 \\
\hline & $(0.5761)$ & $(0.6241)$ & $(0.5136)$ \\
\hline \multirow{2}{*}{ Interest Rate } & 0.1094 & 0.1021 & 0.0632 \\
\hline & $(0.0709)$ & $(0.0724)$ & $(0.0618)$ \\
\hline \multirow{2}{*}{ GDP } & -0.0485 & $-1.7183^{*}$ & $-2.0457 * *$ \\
\hline & $(0.0709)$ & $(0.7420)$ & $(0.6520)$ \\
\hline \multirow{2}{*}{ Capital Adequacy } & $-0.435^{* *}$ & $-0.520^{* *}$ & $-0.6220^{* *}$ \\
\hline & $(0.647)$ & $(0.738)$ & $(0.508)$ \\
\hline \multirow{2}{*}{$\begin{array}{l}\text { Cost to Income } \\
\text { (CIR) }\end{array}$} & -0.3133 & $0.4805^{* *}$ & $0.5579 * *$ \\
\hline & $(0.4035)$ & $(0.5339)$ & $(0.4815)$ \\
\hline \multirow{2}{*}{ Liquidity (LIQ) } & 0.2278 & $1.2741 * *$ & $1.1737 * *$ \\
\hline & $(0.3457)$ & $(0.4861)$ & $(0.3578)$ \\
\hline \multirow{2}{*}{ Profitability (PROF) } & $-0.5527 * *$ & $-0.6130 * *$ & $-0.4754 * *$ \\
\hline & $(0.1789)$ & $(0.1957)$ & $(0.1745)$ \\
\hline \multirow{2}{*}{$\begin{array}{c}\text { Log of total assets } \\
\text { (LSIZE) }\end{array}$} & $-0.1673^{*}$ & -0.1800 & -0.2128 \\
\hline & $(0.0778)$ & $(0.2156)$ & $(0.1739)$ \\
\hline Observation & 112 & 112 & 112 \\
\hline R-sq & 0.131 & 0.440 & 0.422 \\
\hline Long-run Variance & & 0.6433 & 0.6760 \\
\hline
\end{tabular}

The results, as presented in Table 6 , reveals that four bankspecific variables are statistically significant in terms of their relationship with NPLs. These variables include capital adequacy, liquidity, profitability, and cost-to-income ratio (efficiency). The inverse relationship between capital adequacy and NPLs indicates that increase in the capital adequacy ratio of Ghanaian banks leads to a reduction in the NPLs and vice versa. One possible explanation of this result is that banks with low capital adequacy may be compelled to engage in risky lending venture which may result in high NPLs. Conversely, banks with high CAR may refrain from venturing into the provision of high-risk loans and hence minimize their NPLs in the long-run. This result is in agreement with the study by [32] who observe that wellcapitalized financial institutions are better placed to minimize credit risk. It is also in tandem with the risky project hypothesis by [33] which explain that banks may engage in risky lending to enhance their capital or profitability position.

As expected, high cost-to-income ratio (CIR), which indicates bank inefficiency, has a significant positive relationship with NPLs. This result implies that an increase in the cost-to-income ratio leads to high non-performing loans. The high CIR is a sign of inefficiency in the banking sector and therefore banks that are inefficient are likely to experience high NPLs. Inefficient banks are likely to ignore good lending principles and engage in risky lending activities that may jeopardize their credit quality. Again, inefficient banks may poorly allocate resources to monitor the activities of borrowers, which may be a cause of the significant positive relationship between bank CIR and NPLs. This result is in agreement with the bad management hypothesis put forward by [33], which suggest that managers who are inefficient may not be able to cope adequately with credit risk management, 
and hence force their banks into the problem of NPLs. The result is also consistent with the findings of [34] and [35].

Bank liquidity, measured by total loans to total deposits, was also found to be a significant determinant of NPLs within the banking sector of Ghana. The significant positive relationship between liquidity and NPLs suggests that increase in liquidity leads to increase in NPL. A possible explanation for the significant positive relationship between NPLs and liquidity is that banks with high levels of liquidity are likely to engage in extensive lending, which may expose them to high NPLs. Conversely, banks with low liquidity may not have the resources to lend and hence may be less exposed to credit risk. In other words, banks with excess liquidity may pushed to advance loans to borrowers without the necessary due diligence. Such behaviour is likely to result in high NPLs.

We also observe from the analysis of the data to the effect that there is a significant negative relationship between NPLs and profitability of the banks, implying that increase in profitability position of banks result in a reduction in the NPLs levels. This result is not surprising since profitable firms may not be in the rush to engage in risky lending. Also, profitable firms are likely to devote adequate resources to manage and effectively monitor their borrowers which will result in the reduction of NPLs. This findings is also in agreement with existing studies such as [36] and [37].

The result from our study, however, shows that interest rate and inflation have positive but insignificant relationship with NPLs. Also, bank size, measured by the logarithm of total assets, has an inverse but insignificant relationship with NPLs, implying that there is no significant difference between larger banks and their smaller counterparts in terms of the level of default risk they face.

\section{CONCLUSION AND POLICY IMPLICATIONS}

The financial sector, to a large extent, it the backbone of every economy and therefore poor performance of the sector could have dire consequences on the economy as a whole. The Ghanaian banking crises in 2017/2018 and its negative implications for the economy is a clear evidence to support the germane role of the financial sector in the economy. Among the factors cited for the collapse of some banks during the banking crisis is the high levels of NPLs within the sector. Whereas it is important for key stakeholders to take steps to minimize high levels of NPLs, such a move can yield the needed results if the underlying determinants of NPLs are known. Against this backdrop, our study examined the macroeconomic and bank-specific factors that could influence NPLs within the Ghanaian banking industry. To achieve the aim of the study, panel cointegration techniques were employed. These techniques are useful for examining the long-run relationship between variables. Specifically, panel cointegration techniques such as FMOLS and DOLS were applied. These techniques provide robust results and minimize sample bias that could affect the estimates. Our findings support the need for the government of Ghana to take steps to improve the real sector of the economy since such a move will not only enhance the well-being of the general population but also minimize the likelihood of default risk. This will go a long way to ultimately avert possible banking crises as witnessed in the economy from 2017 to 2018. Our findings also underscore the need for banks to improve their capital adequacy, profitability and efficiency position since these bank-specific interventions could significantly minimize the level of NPLs.

Although the current study provides insight into the determinants of NPLs, the study, like all other studies, has some limitations that need to be highlighted. First, the study was limited to Ghanaian banks and therefore the results must be interpreted with caution. Also, whereas there are a plethora of factors that could explain NPLs within the banking sector, this study considered only macroeconomic and bank-specific factors and their implications on NPLs. In view of this limitation, future researchers may consider other possible determinants of NPLs such as bank ownership, exchange market conditions, industry indicators, lending policy indicators, among others.

Furthermore, we propose that future studies on the determinants of credit risk in Ghana should focus on rural banks and microfinance institutions since these institutions are also affected significantly by NPLs.

\section{REFERENCES}

[1] B. S Bernanke: The financial accelerator and the credit channel Remarks by Mr Ben S Bernanke, Chairman of the Board of Governors of the US.

[2] P. Jorion, Financial risk manager handbook. New Jersey: John Wiley \& Sons, Inc. 2009

[3] Basel Committee on Banking Supervision. (2001). Risk management practices and regulatory capital: Cross-sectorial comparison. Switzerland: Bank for International Settlements.

[4] P. P. Athanasoglou, S.N. Brissimis, and M.D. Delis, "Bank-specific, industry-specific and macroeconomic determinants of bank profitability," Journal of International Financial Markets, Institutions and Money, Vol.18, No. 2, pp. 121-136, 2008. Pricewaterhouse coopers (2014), Ghana Banking survey, 2014.

[5] V. G. Hennie, "Analyzing and Managing Banking Risk: A Framework for Assessing Publications (2003).

[6] D. K. Gar, "Determinants of credit risk in the Banking industry of Ghana, Developing country studies," Vol 3 No. 11, pp. 64-77, 2013.

[7] A. Katchova, "Panel Data Models, Econometrics , retrieved from Academy,https://sites.google.com/site/econometricsacademy/home/ab out-the-instructor, 2013.

[8] P. C. B. Phillips and B. E. Hansen, Statistical Inference in instrumental variables resgression with I(1) Process. The review of Economic studies, vol. 57, No. 1, pp. 99-125, January, 1990.

[9] B. Bernanke, M. Gertler, and S. Gilchrist, The financial accelerator in aquantitative business cycle framework. In: Taylor, J.B., Woodford, M (Eds.), Handbook of Macroeconomics. Elsevier, Amsterdam. 1999.

[10] B. Bernanke, M. Gertler, "Agency costs, net worth, and business fluctuations," Am. Econ. Rev. Vol. 79, pp. 14-31. 1989.

[11] R. Beck, P. Jakubik, and A Piloiu, "Key determinants of nonperforming loans: new evidence from a global sample" Open Econ Rev. Vol. 26, No. 3, pp. 525-550, 2015.

[12] E. Nikolaidou, S. Vogiazas, "Credit risk determinants in SubSaharanbanking systems: evidence from five countries and lessons learnt from Cen-tral East and South East European countries". Rev. Dev. Finance 7, 52-63. 2017

[13] A. Pruteanu-Podpiera, A., Weill, L. \& Schobert, F. Banking Competition and Efficiency: A Micro-Data Analysis on the Czech Banking Industry. Comp Econ Stud 50, 253-273 (2008) https://doi.org/10.1057/palgrave.ces.8100248.

[14] A. Ali, K. Daly, "Macroeconomic Determinants of credit risk : Recent evidence from a cross country study" International review of financial analysis, Vol. 19, No. 3, pp. 165-171, 2010.

[15] T. R. Mpofu and E. Nikolaidou, "Determinants of Credit Risk in the Banking system in Sub-Saharan Africa," School of Economics Macroeconomic Discussion Paper Series 2018-04, School of Economics, University of Cape Town. 2018.

[16] N. Haniifah, "Economic determinants of non-performing loans in Ugandan commercial bank.” Taylor's Bus. Rev. J. Vo. 5, No. 2), $137-$ $153,2015$. 
[17] L. Etale, P.E Ayunku, E. Etale, "The impact of non-performing loans andbank performance in Nigeria". Int. J. Humanit. Soc. Sci. Invent. 5 (4), 1-5. 2016

[18] R. De Bock, R., A. Demyanets, "Bank Asset Quality in Emerging Markets: Determinants and Spillover," IMF Working Paper 12/71. 2012.

[19] V. Castro, "Macroeconomic determinants of the credit risk in the banking system: the case of the GIPS," Econ. Model. Vol. 31, P. 672$683,2013$.

[20] BOG, 2015, annual reports publications, 2015.

[21] Communications Department (14 August 2017). "Gcb Bank Ltd Takes Over Ut Bank Ltd And Capital Bank Ltd" (PDF). bog.gov.gh. Bank of Ghana. Retrieved 23 February 2020.

[22] D. Asteriou, and S.G. Hall, “Applied econometrics." New York, NY: Palgrave Macmillan. (2011).

[23] C. F. Mela, and P.K. Kopalle, "The impact of collinearity on regression analysis: the asymmetric effect of negative and positive correlations," Applied Economics, Vol 34. pp. 667-677, 2002.

[24] P. E. Green, J. D. Carroll, and W.S DeSarbo, "A New Measure of Predictor Variable Importance in Multiple Regression," Journal of Marketing Research, Vol. 3 pp. 356-60, 1978.

[25] D. R. Lehmann, "Market Research and Analysis", Homewood, IL: Richard D. Irwin. 1989).

[26] A. Levin, C.F. Lin, and C. Chu, "Unit root tests in panel data: asymptotic and finite sample properties," Journal of Econometrics, vol. 108 , pp. 1-24, 2002.

[27] J. Breitung, "The local power of some unit root tests for panel data," Advances in Econometrics, vol. 15, pp.161-177, 2000.

[28] M. H. Pesaran, Y. Shin, "Impulse Response Analysis in Linear Multivariate Models," Economics Letters, Vol. 58, pp.17-29, 1998.

[29] P. Pedroni, "Critical Values for Cointegration Tests in Heterogeneous Panels with Multiple Regressors," Oxford Bulletin of Economics and Statistics, Vol.61, pp.653-70, 1999.

[30] C. Kao, "Spurious regression and residual-based tests for cointegration in panel data, Journal of Econometrics", 90, pp.1-44, 1999.

[31] A. Poudel and M Ravi (2013) "Macroeconomic Determinants of Credit Risk in Nepalese Banking Industry," Proceedings of 21st International Business Research Conference 10 - 11 June, 2013, Ryerson University, Toronto, Canada.

[32] A. N. Berger, and R. DeYoung, "Problem Loans and Cost Efficiency in Commercial Banks", Journal of Banking and Finance, Vol. 21, pp. 849-870, 1997.

[33] S. walid, Z. Khrawish, Husni \& A. A. Ali, "The utilizing of financial analysis in rationalizing decision of granting credit facilities.' International Research Journal of Finance and Economics, Vol. 69, No. 11, 2011.

[34] S. F de Lis, J. M. Pagés and J. Saurina, "Credit Growth, Problem Loans and Credit Risk Provisioning in Spain", No 0018, Working Papers, Banco de España, 2000.

[35] T.A Tehulu, D.R. Olana, "Bank-Specific Determinants of credit risk: Evidence from Ethiopian banks", Research Journal of Finance and Accounting, Vol. 5, No. 7, pp. 80-86.

[36] M. Quagliariello, "Banks' Riskiness over the Business Cycle: A Panel Analysis on Italian Intermediaries", Applied Financial Economics. Vol. 2, No. 17, pp. 119-138., 2007.

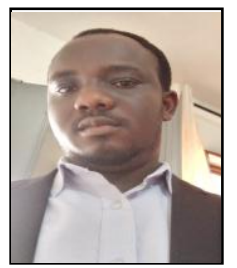

Thomas Appiah is a PhD. Candidate with UNICAF University, Malawi, and currently holds an M-phil degreee in Finance from the Kwame Nkrumah University of Science and Technology and a bachelor's degree in Economics from the University of Ghana. He is currently a lecturer with the department of accounting and Finance, Ghana Technology University College.

He has published in a number of international journals and also attended a number of local and international conferences. His research interest is in the areas of financial technology and innovation, financial markets, and SMEs financing. He can be contacted through the following e-mail address: appiah.thomas225@gmail.com.

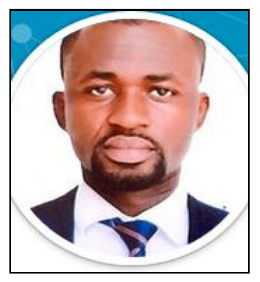

Frank Bisiw holds an M-phil degree in Business Consulting and Enterprise Risk Management from the Kwame Nkrumah University of Sceince and Technology, and a bachelor of education in Economics from the university of Cape Coast, Ghana.

$\mathrm{He}$ is an experienced banker who has worked in several financial institutions in Ghana, including the Royal Bank and the Sahel Sahara Bank. 